\title{
Quando se vai um que estava sob nosso cuidado*
}

When someone under our care passes away

Merval Marques Figueiredo Junior ${ }^{1}$

2 Centro de Atenção

Psicossocial,

equipamento

comunitário de atenção

em saúde mental, que

atende principalmente

pessoas com

transtorno mental

severo em diversos

níveis de complexidade,

oferecendo uma gama

de atividades que visam

primordialmente à

reinserção social.

${ }^{3}$ Pessoa da instituição responsável por

estabelecer o percurso

do usuário no serviço.
O falecimento de Patrícia G. pegou a todos de surpresa. Usuária do CAPS² há vários anos, jovem de trinta e sete anos, separada, mãe de três filhos - 18, 16 e 12 anos -, participava com regularidade do cotidiano da instituição. Não conseguia trabalhar. Não conseguia cuidar dos filhos. Morava em albergue. Além dos problemas psíquicos que eram motivo de sua freqüência ao serviço, sofria de hipertensão arterial, obesidade e problemas cardíacos para os quais usava diversos medicamentos clínicos. Lembro-me de que certa vez fui acionado para medicá-la devido a um pico hipertensivo. No início deste ano Patrícia não apareceu ao CAPS como era seu costume. Passados alguns dias sua referência ${ }^{3}$, Carla Lemos, procurou saber a seu respeito. Após uma longa busca entre familiares, conhecidos, albergues, hospitais gerais e psiquiátricos, Carla descobriu em um Hospital geral que a Patrícia havia falecido no início do ano devido a edema pulmonar, após passar alguns dias em UTI.

Espanto, indignação, tristeza, e outros sentimentos emergiram entre técnicos e usuários. Alguns reclamaram da falta da assistência clínica no CAPS; outros pelo longo tempo que se levou para descobrir seu paradeiro; outros (usuários) "que bom, merecia morrer mesmo"; outros (usuários) manifestaram crise emocional. Da minha parte me cobrei por não me lembrar imediatamente dela - reconhecer todos os usuários do cotidiano pelo nome é comum nesta casa.

Não é intenção deste texto encontrar o "onde erramos" ou explorar a mea culpa. Antes, proponho uma reflexão sobre as pequenas e grandes atitudes do dia a dia da instituição - as relações entre funcionários e usuários, e dos funcionários entre si - que demonstram uma certa ética, que a faz distinguir-se na rede pública.

\footnotetext{
"Texto originalmente apresentado ao CAPS "Prof. Luís da Rocha Cerqueira"/SP, em fevereiro de 2000 . Agradecimento especial a Carmem Banho. O texto baseia-se na conferência de Agnes Heller: "Ética elementar da vida cotidiana", proferida na PUCSP em 10/ 05/92, tradução de Rachel Machado de Moraes e Ricardo Rodrigues Teixeira, mimeo.

${ }^{1}$ Médico psiquiatra e sanitarista; Assessor de Saúde Mental da Coordenadoria de Saúde da Região Metropolitana da Grande São Paulo, Secretaria de Saúde do Estado de São Paulo. <merval@bol.com.br>
} 
Os novos serviços de Saúde Mental, dentre os quais o CAPS, diferenciam-se dos "antigos" pela atitude performativa de seu pessoal. Estes serviços distinguem-se daqueles serviços "manicomiais, institucionalizadores, cristalizados" por encontrarmos neles um número proporcionalmente elevado de pessoas decentes, seres morais - com isto quero dizer que nesses serviços a maioria das pessoas escolhe, a partir de seu centro, serem pessoas decentes, moralmente orientadas.

"Uma pessoa decente - diz Agnes Heller - nota o sofrimento dos outros; faz o seu melhor para aliviar o sofrimento alheio; oferece parte do seu tempo, dinheiro e energia para alívio de um sofrimento." Não porque siga um ditame religioso, mas por uma decisão de foro íntimo. Sartre disse, em algum lugar, que estamos condenados a ser livres. O sujeito moral é aquele que é livre para escolher seus princípios morais, e livre para decidir segui-los ou não. Escolhe-se ser um ser moral, uma pessoa decente, a partir de nosso centro. Onde uma pessoa diz "meu centro", lembra Heller, escuta-se "minha responsabilidade".

A atitude da Carla deveria ser no mínimo, corriqueira entre nós, profissionais da saúde: a de estarmos preocupados com o outro, a de assumirmos responsabilidade pelo outro. Responsabilidade é, em geral, um dos conceitos morais fundamentais - todo tipo de responsabilidade é, no fundo, uma responsabilidade moral. A palavra "responsabilidade" tem a mesma raiz que "responder". A pessoa que responde por algo ou alguém é verdadeiramente responsável.

Assumir a responsabilidade é o ponto de partida, sua extensão é "viver" para a responsabilidade assumida enquanto os outros precisarem de nós. A diretoria de uma instituição de saúde é responsável por todos seus pacientes, como também pelos seus funcionários; a pessoa que é referência no CAPS é responsável por certo número de usuários. Viver para a responsabilidade é um passo além de assumir uma responsabilidade - traduz-se tomar o "encargo para si”. Assume-se que os pais são responsáveis por seus filhos - eles respondem pelos atos dos filhos enquanto menores de idade -, daí segue que eles podem viver para essa responsabilidade - eles farão tudo que lhes for possível para que os filhos cresçam da melhor forma.

Assumir e viver para a responsabilidade são elementos que diferenciam os "antigos" dos novos serviços de saúde mental, ou renovados como querem alguns. Uma cena que presenciei no CAPS: Marta, terminada sua jornada de trabalho, já no final da tarde, em um dia em que não é responsabilidade de sua mini-equipe atender as ocorrências, percebe que sua presença é necessária para auxiliar um usuário em crise (não é sua referência, nem paciente de sua miniequipe) e permanece para ajudar a diminuir o sofrimento - isto é viver para a responsabilidade, e se revela com a genuína preocupação com o outro. Outro evento: em pleno domingo Beatriz vem ao serviço e se pendura em uma marquise, com risco de cair e ferir-se gravemente. O segurança da unidade tenta localizar os responsáveis pela usuária telefonando para várias pessoas. Telma é a primeira a chegar, responsável pelo almoxarifado, não é técnica, não trata diretamente com usuários, mas conhece-os todos, sua presença é fundamental para resolver a situação. Esta é uma situação usual das pessoas num CAPS: o desprendimento interno e a preocupação para com as pessoas do serviço. 
Preocupar-se com outros seres humanos, esse é o princípio orientador universal da moral. Aceita -se que seja universal porque em todas as esferas, em todas as formas da vida, em todos os tipos de atividades, as pessoas podem ou não se preocupar umas com as outras. É um princípio orientador porque não determina como devemos nos preocupar com outros seres humanos. Compete a cada um descobrir qual a melhor maneira de se preocupar com esse ou aquele ser humano.

Agnes Heller enumera alguns princípios orientadores: ter justa consideração pela vulnerabilidade e pela autonomia de outras pessoas; pela moralidade e pelo sofrimento dos outros.

Todos esses princípios orientadores soam e realmente são simplesmente bem tradicionais. Os princípios orientadores acima enumerados - continua Heller - são apenas interpretações/explicações do princípio orientador universal:

Preocupar-se com outros seres humanos - não prejudicar propositadamente outros seres humanos. É óbvio que o próprio princípio universal não é incompatível com possíveis sub-princípios que estimulam a autonomia. Não há razão para ficar embaraçado diante dessa descoberta. O princípio universal de orientação moral é o arche da moral. É o meta-princípio de um sistema. Pode haver conflito entre eles. Mas todos eles devem ser formulados de tal forma que a fórmula seja compatível com a liberdade e a autonomia.

Parece redundante dizer que a tarefa dos profissionais de saúde é a de estar preocupados com a saúde das pessoas; fazer o possível para recuperar-lhes a saúde; de fazer o possível neste movimento, em não causar dano. Parece óbvio, e é. Afinal, isto está implícito na escolha profissional. Em algumas instituições, contudo, as pessoas parecem se esquecer desse princípio moral. Uma instituição burocratizada - como diz Jurandir Costa (1992) - onde os pacientes são fichas, números, pessoas sem rostos, rostos sem "pessoalidade"; onde os salários são baixos; a auto-estima está comprometida; a hierarquia não está estabelecida por méritos. Nesse tipo de instituição é mais fácil encontrarmos técnicos indiferentes ao sofrimento alheio. Nesse tipo de instituição o bom paciente é aquele que não demanda atendimento, que não incomoda, melhor seria se morto estivesse porque um a menos seria. O que seria de nossos usuários se números, fichas, o fossem? Talvez, quem sabe, seis meses depois, quando por falta de comparecimento, o prontuário da Patrícia fosse remanejado da estante "ativo" para a de "inativo", um funcionário do setor do arquivo sem envolvimento com o projeto pensasse: "Puxa, como este serviço é um saco!". Infelizmente este é ainda o tipo de muitos funcionários públicos. Enquanto uns lutam por fazer a rede pública digna e democrática para o cidadão, outros cruzam os braços, permitindo a iniqüidade e a burocracia.

o que diferencia os novos serviços de saúde mental é que a maior parte das pessoas que ali trabalham sabem que vão trabalhar com psicóticos $e$ 
escolheram isto; sabem que terão colegas - que carregam sonhos, angústias $e$ modos idiossincráticos de ser -, que escolheram isto; sabem que vão trabalhar no serviço público, sujeito a todas as variações políticas e econômicas, $e$ escolheram isto - escolheram porque se importam com o psicótico.

Em sua tese de mestrado, Maria Tavares Cavalcante (1992) fala da relação entre desejo e ética. A opção de trabalhar em um CAPS, em uma enfermaria de Saúde Mental, em uma emergência psiquiátrica, em uma Unidade Básica de Saúde, em locais de contato direto com psicóticos, é uma escolha. Em Lacan nos lembra Cavalcante - encontramos que o campo ético é refletido pela quantidade de desejo (movimento inconsciente) presente na ação. Sem esta dimensão desejante não há como tratar psicóticos, pois não há a menor possibilidade de disponibilidade, de heterogeneidade, enfim, de Encontro.

A autora nos conta da experiência de Oury, diretor da Clínica La Borde, na França. O psiquiatra francês diz que nas instituições há dois grupos de pessoas: aquelas "que se importam", e aquelas para as quais "tanto faz". Para que uma instituição funcione terapeuticamente é preciso um certo número de pessoas do grupo "que se importam". Lembremos que esta divisão não é maniqueísta, dos "bons" contra os "maus", mesmo porque em alguns momentos acontece de as pessoas passarem da posição dos "que tanto faz" para a "dos que se importam" e vice-versa, e esta posição varia sobre um mesmo evento no tempo $e$ entre instituições. É comum encontrarmos nas instituições pessoas que iniciam o trabalho na posição "que se importam" para depois de um certo tempo cair no outro grupo. O grupo dos "que se importam" também pode ser chamado "dos que se preocupam". Quando a Carla foi em busca da Patrícia ela se dizia: "eu me importo com a Patrícia"; estava respondendo a uma pergunta nuclear em ética: "Qual a coisa certa para eu fazer?".

Nos CAPS e serviços similares, vivemos o risco constante de nos transformarmos em instituição burocrática, de sermos um serviço no qual a grande maioria se converta ao grupo do "tanto faz" - também sofremos de algumas mazelas do serviço público, como os baixos salários, as infindas demandas, as angústias dos usuários - muitos necessitando de atendimento que não temos como resolver - mas nem por isso rebaixamos nossos valores éticos. Mantemos de certa forma este espírito, porque seguimos algumas normas de convívio.

As regras elementares da ética cotidiana que guiam as ações humanas podem ser descritas em termos de reciprocidade. Exemplos comuns de reciprocidade são as saudações: "bom dia; boa tarde; até logo", o aperto de mãos. A reciprocidade se caracteriza pelo dar e receber. Quando uma pessoa dá $e$ outro não recebe, não há relacionamento. Quando um dá e outro só recebe há um relacionamento, mas não há reciprocidade. Nem sempre podemos retribuir com o mesmo valor, por isto a reciprocidade pode ser simétrica ou assimétrica.

Ao assumirmos a responsabilidade por outro, estabelecemos uma relação assimétrica. Faço o melhor para diminuir o sofrimento alheio, não porque ele aliviou ou poderá vir a aliviar meu sofrimento. Não se faz o bem esperando receber algo em troca, fazemo-lo por uma escolha moral. Os usuários estabelecem conosco esta reciprocidade assimétrica (embora sejamos pagos para atendê-los). Eles agradecem nosso esforço e empenho, organizando uma 
festinha, escrevendo uma poema, dizendo "Deus te abençoe" (dando a benção). Os profissionais da saúde mental, em geral, temos mais recursos que outros profissionais da saúde em escutar, especialmente agradecimentos. Onde alguns ouviriam apenas "comentários vazios", um bom "mentaleiro" percebe algo mais. Outra cena de um serviço novo: Josafá, usuário, aproximou-se de Clarice, uma aprimoranda, e começou a falar sobre o belo trabalho que os missionários de sua igreja fazem: o de ir na casa dos doentes, levar conforto e esperança. Falava com desenvoltura e satisfação de um trabalho de que nunca participou e que gostaria se tivesse oportunidade. Sem diretamente agradecer, elogiava assim o trabalho de Clarice, que lhe fez visita domiciliar quando ele não esteve bem.

Retribuímos ao serviço por nossos atrasos, ficando uma hora a mais quando solicitado ou não. A diretoria também retribui reconhecendo as horas a mais dispensadas pelo funcionário que leva um usuário a outro serviço de saúde, lá ficando quase o dia inteiro. Assim como eu, técnico, atendo (se posso fazê-lo) um paciente quando um colega faltou. Assim os colegas substituindo uns aos outros em suas ausências, faltas e esquecimentos, para que a pessoa que está sob nosso encargo, da instituição, não padeça pelas omissões dos funcionários do serviço. Estabelece-se, assim, um jogo de reciprocidade dinâmico. Conforme for a ligação entre seus participantes, este jogo pode ser forte, melhorando a instituição; pode ser fraco, se uns funcionários se sentirem explorados por outros, levando o serviço à ruína.

Para manter o jogo da reciprocidade, lembra Heller

deve-se observar algumas regras daquilo que não é permitido no jogo
de dar/receber. Primeiro, é vergonhoso quebrar a corrente do dar/
receber, quando for a nossa hora de reciprocar - contudo, há exceções.
É sempre errado usar as regras de reciprocidade para instrumentalizar
as outras pessoas. É moralmente errado fazer algo a alguém esperando
receber o mesmo de volta sem revelar seu propósito para o receptor.
Não é correto pedir um favor a alguém que se despreza e vilipendia.
Não é correto fingir sentimento a fim de levar alguém a fazer um
serviço, a um favor, ou desejando transferir coisas a ele. Não é correto
fingir sentimento quando recebemos algo (agradecer é uma atitude
correta, fingir a gratidão é errado). É errado se dar coisas ou prestar
serviços, a fim de ser reciprocados com sentimentos.

Qual a importância, então, deste discurso sobre a ética do cotidiano em nossa instituição? Ele nos toca por vários motivos: seja porque agora que se discute no CAPS "Luís Cerqueira", após um seminário de avaliação interna, o que é um CAPS; seja para direcionar ativamente a instituição no avanço da Reforma Sanitária (leia-se Saúde em geral, não só Reforma Psiquiátrica); seja porque o Ministério da Saúde, para poder financiar este tipo de equipamento de saúde, normatizou, por meio de portaria, o aspecto formal de um CAPS (funcionar vinte e quatro horas por dia; ter leitos de retaguarda; ter atividades específicas; ter tantos e tantos funcionários, de tais e tais profissões etc.); seja porque um equipamento de saúde não deve, nem pode ficar muito tempo subutilizado, quando a esmagadora maioria dos serviços públicos de saúde 
estão sobrecarregados. Sabemos que a forma é importante para a identidade de um equipamento, mas as relações internas entre os funcionários, e destes com o público a quem serve, é que faz a diferença. Sarraceno (1996) diz que estes elementos "não palpáveis" são indicadores "soft"; quanto melhor estes indicadores, melhor a instituição.

Quando os diretores (não só enquanto gerentes) e vários outros trabalhadores se preocupam em como dar a notícia do falecimento da Patrícia aos demais usuários do serviço e contornar possíveis crises - demonstra-se a preocupação com eles. Quando se fala em desinstitucionalização, de Reforma Psiquiátrica, não estamos falando simplesmente do reordenamento de estruturas de serviços (extinção gradativa dos manicômios, criação de serviços alternativos etc.) mas que estes novos serviços sejam preenchidos por um espontâneo espírito de ética cotidiana, $e$ isto não pode ser determinado por uma norma do Ministério da Saúde.

A pretensão deste texto não foi a de elogiar os serviços "alternativos" como lugares plenamente éticos, que não o são, somos humanos; nem tampouco poderia ter como pretensão esgotar a questão da ética cotidiana no CAPS. Parafraseando Jurandir Costa (1994), diria que somos humanos, e ser humano é falar, e quem fala se engana, erra, acerta, volta atrás, em suma, faz tudo aquilo que dá sentido e valor a palavras como responsabilidade, preocupar-se com e reciprocidade. O valor surgirá como resposta à pergunta "O que eu devo fazer", "Qual é a coisa certa para eu fazer?" - interroguemos nosso desejo, vejamos o quanto isto reflete a ação, o quanto estamos conscientes desses princípios. Tomar consciência deles é um dos passos para evitarmos erros que não têm conserto, como a perda de uma usuária.

Referências bibliográficas:

CAVALCANTE, M. T. O tear das cinzas. Rio de Janeiro, 1992. Tese (Mestrado), Instituto de Psicologia da Universidade do Brasil, Universidade Federal do Rio de Janeiro.

COSTA, J. F. A ética e o espelho da cultura. Rio de Janeiro: Rocco, 1994.

COSTA, J.F. Psiquiatria burocrática, duas ou três coisas que sei a respeito. In: BIRMAN, J. (Org.) Clínica do Social. São Paulo: Escuta, 1992. p.39-74.

SARRACENO, B. Reabilitação psicossocial: uma prática à espera de teoria. In: PITTA, A. (Org.)

Reabilitação Psicossocial no Brasil. São Paulo: Hucitec, 1996. p.150-4.

Baseando-se em uma conferência de Agnes Heller, o autor desenvolve uma reflexão sobre o cotidiano de uma instituição de Saúde Mental, em particular sobre as relações éticas vivenciadas por funcionários e usuários, que a faz distinguir-se da rede pública de saúde.

PALAVRAS-CHAVE: Ética médica; Saúde Mental; relações médico-paciente. KEY WORDS: Medical ethics; Mental Health; physician-patient relations. PALABRAS CLAVE: Ética medica; Salud Mental; relaciones medico-paciente.

Recebido para publicação em: 22/02/01. Aprovado para publicação em: 15/05/01. 